UPAYA MENINGKATKAN KEDISIPLINAN SISWA MELALUI LAYANAN PENGUASAAN KONTEN DENGAN TEKNIK MODELLING PADA SISWA KELAS VII SMP NEGERI 8 TEBING TINGGI

\title{
Debora Simanungkalit
}

Surel: deborasimanungkalit@gmail.com

\begin{abstract}
ABSTRAK
Permasalahan yang dikaji dalam penelitian ini adalah mengetahui gambaran kedisiplinan siswa kelas VII dalam menaati tata tertib sebelum dan setelah diberi layanan penguasaan konten dengan teknik modelling. Jenis penelitian adalah penelitian eksperimen. Populasi penelitian ini adalah semua siswa kelas VII SMK Negeri 1 Tebing Tinggi. Teknik sampling yang digunakan adalah Cluster Random Sampling dan kelas VII PM yang menjadi sampel penelitian dengan jumlah responden 32 siswa. Hasil penelitian yang diperoleh, tingkat kedisiplinan siswa sebelum mendapatkan layanan penguasaan konten tergolong dalam kategori sedang dengan persentase $66,6 \%$. Setelah mendapatkan penguasaan konten persentasenya $77,6 \%$ tergolong kategori tinggi. Dengan demikian mengalami peningkatan sebesar $11 \%$.
\end{abstract}

Kata kunci: Layanan Penguasaan Konten, Modelling, Kedisiplinan

\section{PENDAHULUAN}

Pada saat ini Indonesia telah memasuki era pasar bebas di mana setiap orang dapat memasuki Indonesia untuk beraktifitas tanpa melihat kewarganegaraannya. Kondisi ini menuntut setiap warga negara Indonesia untuk mampu bersaing dengan warga negara lain karena tonggak kemajuan sebuah bangsa untuk bisa bersaing di pasar bebas bergantung pada mutu sumber daya manusia yang dimiliki. Oleh karena itu, diperlukan berbagai macam kompetensi dan kecakapan hidup yang harus dimiliki oleh warga negara Indonesia agar mampu bersaing dengan warga negara lain. Salah satu kompetensi tersebut adalah disiplin diri. Disiplin merupakan bentuk perilaku patuh dan tunduk terhadap peraturan yang berlaku tetapi kepatuhan itu lebih ditekankan pada kesadaran diri bukan karena paksaan. Akan tetapi pada kenyataannya banyak perilaku disiplin manusia yang dilatarbelakangi karena adanya paksaan atau aturan yang mengekang. Sehingga asumsi yang berkembang di kalangan masyarakat bahwa disiplin itu berarti kaku dan menakutkan. Mengutip pernyataan dari Durkheim (1990: 35) yang menyebutkan bahwa disiplin mempunyai tujuan ganda yaitu untuk mengembangkan suatu keteraturan tertentu dalam tindak-tanduk manusia dan memberikan suatu sasaran tertentu yang sekaligus juga membatasi cakrawalanya. Disiplin merupakan salah satu kecakapan hidup yang sangat penting dan perlu dimiliki oleh setiap orang guna 

mencapai kesuksesan dalam hidupnya, tidak hanya kesuksesan dalam belajar tetapi juga kesuksesan dalam hidup bermasyarakat. Akan tetapi, tidak dapat dipungkiri jika masih banyak orang yang tidak menerapkan disiplin dalam kehidupannya. Terdapat banyak alasan mengapa seseorang tidak dapat berlaku disiplin, diantaranya adalah malas, belum terbiasa dengan disiplin, dan belum mampu bersikap tegas pada diri sendiri. Oleh karena itu, diperlukan adanya sebuah upaya agar seseorang dapat berlaku disiplin. Salah satu caranya adalah melalui pendidikan baik pendidikan formal maupun non formal. SMP Negeri 8 Tebing Tinggi adalah salah satu sekolah menengah Pertama dengan standar nasional. Sebagian besar siswa di sekolah ini berasal dari kalangan keluarga menengah ke bawah, meskipun juga terdapat beberapa siswa yang berasal dari ekonomi mampu. Jadi siswa yang bersekolah di tempat ini heterogen, mereka mempunyai kebiasaan yang berbeda-beda baik dari cara belajar, bergaul hingga dalam mematuhi peraturan yang telah ditetapkan oleh pihak sekolah. Seperti halnya di sekolah lain di SMP Negeri 8 Tebing Tinggi juga terdapat peraturanperaturan yang harus ditaati oleh setiap siswa. Peraturan ini ditetapkan dengan tujuan agar para siswa berhasil dalam menuntut ilmu selama berada di SMP Negeri 8 Tebing Tinggi. Peraturan yang ada di sekolah ini tidak hanya berkaitan dengan hal belajar tetapi juga dalam hal beribadah dan bersosialisasi dengan orang lain. Hal ini bertujuan agar setiap siswa dapat berlaku disiplin dalam segala aspek kehidupan di sekolah pada khususnya dan aspek kehidupan di masyarakat pada umumnya. Berdasarkan hasil pengamatan selama melaksanakan tugas di SMP Negeri 8 Tebing Tinggi peneliti menangkap fenomena banyaknya siswa yang melanggar tata tertib sekolah. Salah satu guru pembimbing di SMP Negeri 8 mengemukakan bahwa seluruh siswa SMP Negeri 8 memahami akan adanya peraturanperaturan yang telah ditetapkan oleh sekolah. Akan tetapi hal tersebut masih berhenti pada tingkat pemahaman saja belum dimanifestasikan dalam sebuah tindakan. Masih terdapat banyak siswa yang tidak mematuhi peraturan yang berlaku sehingga perilaku disiplin belum tampak pada diri setiap siswa. Masalah pelanggaran tata tertib yang dilakukan oleh siswa belum diadministrasikan dengan baik karena tidak adanya petugas khusus yang menangani masalah kedisiplinan siswa. Apabila siswa telah melakukan pelanggaran tata tertib berulang kali biasanya dilimpahkan ke guru pembimbing untuk selanjutnya mendapatkan pelayanan BK.

Berdasarkan hasil studi pendahuluan yang dilakukan oleh peneliti pada saat melaksanakan Kegiatan Mengajar di SMP Negeri 8 Tebing Tinggi diperoleh data bahwa tingkat kesadaran untuk berdisiplin 
Debora Simanungkalit : Upaya Meningkatkan Kedisip ....

siswa masih rendah. Hal ini ditunjukkan dengan masih banyaknya pelanggaran-pelanggaran tata tertib yang dilakukan oleh siswa. Menurut Wijaya (1991: 18) siswa dikatakan disiplin dapat dilihat dari beberapa indikator berikut: melaksanakan tata tertib dengan baik, taat terhadap kebijakan yang berlaku, menguasai diri dan introspeksi (mempunyai sense of responsibility).

Berdasarkan latar belakang yang telah dikemukakan sebelumnya maka permasalahan utama adalah "upaya meningkatkan kedisiplinan siswa dalam menaati tata tertib melalui layanan penguasaan konten dengan menggunakan teknik modelling pada siswa kelas VII SMP Negeri 8 Tebing Tinggi tahun ajaran 2015/2016" yang ingin dikaji lebih lanjut dalam pertanyaan penelitian berikut: (1) Bagaimana gambaran kedisiplinan siswa dalam menaati tata tertib sebelum diberi layanan penguasaan konten dengan menggunakan teknik modelling pada siswa kelas VII SMP Negeri 8 Tebing Tinggi tahun ajaran 2015/2016? (2) Bagaimana gambaran kedisiplinan siswa dalam menaati tata tertib setelah diberi layanan penguasaan konten dengan menggunakan teknik modelling pada siswa kelas VII SMP Negeri 8 Tebing Tinggi tahun 2015/2016? (3) Apakah terdapat peningkatan kedisiplinan siswa dalam menaati tata tertib setelah diberi layanan penguasaan konten dengan menggunakan teknik modelling pada siswa kelas VII SMP Negeri 8

Tebing Tinggi tahun 2015/2016?

Berdasarkan

rumusan

masalah yang telah dipaparkan sebelumnya maka tujuan utama dari penelitian ini yaitu untuk mengetahui "upaya meningkatkan kedisiplinan siswa dalam menaati tata tertib melalui layanan penguasaan konten dengan menggunakan teknik modelling pada siswa kelas VII SMP Negeri 8 Tebing Tinggi tahun ajaran 2015/2016". Secara lebih rinci tujuan dari penelitian ini adalah:

a. Untuk mengetahui gambaran kedisiplinan siswa dalam menaati tata tertib sebelum diberi layanan penguasaan konten dengan menggunakan teknik modelling pada siswa kelas VII SMP Negeri 8 Tebing Tinggi tahun ajaran 2015/2016.

b. Untuk mengetahui gambaran kedisiplinan siswa dalam menaati tata tertib setelah diberi layanan penguasaan konten dengan menggunakan teknik modelling pada siswa kelas VII SMP Negeri 8 Tebing Tinggi tahun 2015/2016.

c. Untuk mengetahui peningkatan kedisiplinan siswa dalam menaati tata tertib setelah diberi layanan penguasaan konten dengan menggunakan teknik modelling pada siswa kelas VII SMP Negeri 8 Tebing Tinggi tahun 2015/2016.

\section{METODE PENELITIAN}

Jenis penelitian yang digunakan dalam penelitian ini 
adalah jenis penelitian eksperimental. Instrumen penelitian disusun mengacu pada teori yang digunakan kemudian dikembangkan menjadi kisi-kisi instrumen yang selanjutnya akan disusun menjadi instrumen. Langkah yang selanjutnya adalah melakukan uji coba instrumen yang bertujuan untuk mengetahui kevalidan instrumen tersebut. Setelah dilakukan uji coba kemudian dilakukan perbaikan pada instrumen yang sebelumnya. Hasil instrumen yang telah direvisi (instrumen jadi) akan digunakan untuk memperoleh data dalam penelitian.

Metode pengumpulan data dalam kegiatan penelitian mempunyai tujuan untuk mengungkap fakta mengenai variabel yang diteliti. Data yang diperoleh selanjutnya dijadikan dasar untuk membuat sebuah simpulan dari penelitian. Dalam penelitian ini metode pengumpulan data yang digunakan adalah skala psikologi. Skala psikologi digunakan dalam penelitian ini karena karena variabel yang diungkap (disiplin) termasuk dalam atribut psikologi.

\section{HASIL PENELITIAN DAN PEMBAHASAN}

Dari hasil pre test diperoleh gambaran secara keseluruhan tingkat kedisiplinan siswa dalam menaati tata tertib sekolah berada pada kategori sedang dengan persentase sebesar $67 \%$. Nilai $67 \%$ jika ditinjau dari tabel kriteria tingkat kedisiplinan yang disebutkan pada bab III masuk ke dalam kategori sedang. Dengan kata lain dapat dikatakan bahwa kedisiplinan siswa yang ditinjau dari aspek pemahaman tentang peraturan yang berlaku, sikap mental yang baik, serta kesungguhan dalam menaati tata tertib berada dalam kondisi yang cukup baik.

Berikut ini adalah hasil pre test dari sklala kedisiplinan dalam menaati tata tertib sekolah sebelum diberikan layanan penguasaan konten dengan menggunakan teknik modelling. diperoleh gambaran bahwa sebelum diberikan layanan penguasaan konten dengan menggunakan teknik modelling simbolik dari 32 siswa kelas VII SMP Negeri 8 Tebing Tinggi terdapat 5 siswa $(15,63 \%)$ memiliki kategori tinggi dan 27 siswa $(84,38 \%)$ memiliki kategori sedang dalam hal kedisiplinan menaati tata tertib. Tidak ditemukan adanya siswa yang memiliki tingkat kedisiplinan dalam kategori sangat tinggi, rendah dan sangat rendah. Mengacu pada tujuan kedua dari penelitian ini yaitu untuk mengetahui gambaran kedisiplinan siswa setelah diberi layanan penguasaan konten, maka peneliti memberikan post test setelah memberikan treatment kepada responden. Dari hasil post test $\mathrm{d}$ apat diketahui bahwa secara keseluruhan kondisi kedisiplinan siswa berada pada kriteria tinggi. Hasil ini diperoleh dari skor tota 1 yang diperoleh pada saat pre test sebesar 6173 dan jumlah responden sebanyak 32 siswa. Maka diperoleh skor rata-ra ta sebesar 192,91 atau $77 \%$ dari skor maksi mal seluruh 
item. Nilai $77 \%$ jika ditinjau dari tabel 4.1 masuk ke dalam kriteria tinggi. Atau dengan kata lain kondisi kedisiplinan siswa setelah diberi treatment sudah baik.

\section{Tabel Distribusi Frekuensi Hasil Post test Kedisiplinan Siswa dalam Menaati Tata Tertib}

\begin{tabular}{|l|l|l|}
\hline $\mathbf{F}$ & \% Skor & Kriteria \\
\hline 1 & $3,13 \%$ & $\begin{array}{l}\text { Sangat } \\
\text { tinggi }\end{array}$ \\
\hline 23 & $71,87 \%$ & Tinggi \\
\hline 8 & $25,00 \%$ & Sedang \\
\hline 0 & $0,00 \%$ & Rendah \\
\hline 0 & $0,00 \%$ & $\begin{array}{l}\text { Sangat } \\
\text { rendah }\end{array}$ \\
\hline
\end{tabular}

Dari tabel Distribusi Frekuensi Hasil Post test Kedisiplinan Siswa dalam Menaati Tata Tertib diperoleh gambaran bahwa setelah diberikan layanan penguasaan konten dengan menggunakan teknik modelling simbolik dari 32 siswa kelas VII SMP Negeri 8 Tebing Tinggi terdapat 1 siswa $(3,13 \%)$ memiliki kategori sangat tinggi, 23 siswa $(71,87 \%)$ memiliki kategori tinggi dan 8 siswa $(25,00 \%)$ memiliki kategori sedang dalam hal kedisiplinan menaati tata tertib. Tidak ditemukan adanya siswa yang memiliki tingkat kedisiplinan dalam kategori rendah dan sangat rendah.

Berdasarkan pada data di atas terjadi peningkatan dan penurunan persentase pada beberapa kriteria setelah dilakukan post test. Pada kriteria sangat tinggi terjadi peningkatan sebesar $21,88 \%$ dari kondisi awal. Saat pre test tidak ada siswa yang termasuk ke dalam kriteria sangat tinggi, tetapi hasil post test menunjukkan terdapat 7 $(21,88 \%)$ siswa yang termasuk ke dalam kriteria ini. Hasil pre test menunjukkan terdapat 13 siswa $(40,62 \%)$ yang termasuk ke dalam kriteria tinggi, sedangkan pada hasil post test meningkat menjadi 20 siswa $(62,50 \%)$ dengan kata lain terjadi peningkatan sebesar $21,88 \%$ pada kriteria tinggi. Pada kriteria sedang mengalami penurunan, kondisi awal (hasil pre test) menunjukkan bahwa terdapat $18 \quad(56,25 \%)$ siswa yang masuk ke dalam kriteria sedang dan kondisi akhir (hasil post test) diketahui bahwa siswa yang berada pada kriteria ini sebanyak 5 $(15,62 \%)$ siswa. Dengan kata lain terjadi penurunan sebesar $40,63 \%$ pada kriteria sedang. Hasil pre test menunjukkan terdapat $1 \quad(3,13 \%)$ siswa yang termasuk dalam kriteria rendah, tetapi hasil post test tidak menunjukkan adanya siswa yang masuk dalam kriteria rendah.

\section{Pembahasan}

Berdasarkan pada tujuan dan hasil dari penelitian yang telah dilakukan, maka akan dibahas secara rinci tentang gambaran kedisiplinan siswa kelas VII SMP Negeri 8 Tebing Tinggi dalam menaati tata tertib sebelum diberi layanan penguasaan konten dengan menggunakan teknik modelling, gambaran kedisiplinan siswa kelas VII SMP Negeri 8 Tebing Tinggi dalam menaati tata tertib setelah diberi layanan penguasaan konten 
dengan menggunakan teknik modelling, dan perbedaan kedisiplinan siswa kelas VII SMP Negeri 8 Tebing Tinggi dalam menaati tata tertib sebelum dan setelah diberi layanan penguasaan konten dengan menggunakan teknik modelling. Hasil analisis deskriptif menunjukkan bahwa sebelum diberikan layanan penguasaan konten dengan menggunakan teknik modelling simbolik dari 32 siswa kelas VII SMP Negeri 8 Tebing Tinggi terdapat 5 siswa $(15,63 \%)$ memiliki kategori tinggi dan 27 siswa $(84,38 \%)$ memiliki kategori sedang dalam hal kedisiplinan menaati tata tertib. Tidak ditemukan adanya siswa yang memiliki tingkat kedisiplinan dalam kategori sangat tinggi, rendah dan sangat rendah. Hasil pre test menunjukkan bahwa indikator pemahaman tentang peraturan yang baik mempunyai tingkat persentase yang paling tinggi jika dibandingkan dengan indikator yang lainnya yaitu sebesar (68\%) hal ini dikarenakan pembentukan disiplin menaati tata tertib yang ada di sekolah selama ini lebih banyak ditekankan pada hal pemahaman tentang tata tertib yang berlaku. Sedangkan indikator sikap mental yang baik mempunyai tingkat persentase yang paling rendah saat pre test yakni sebesar $65 \%$. Secara umum kedisiplinan siswa dalam menaati tata tertib dalam kategori sedang, atau dengan kata lain kondisi kedisiplinan siswa dalam keadaan cukup baik. Pada pengamatan awal sebelum dilaksanakan penelitian terlihat bahwa siswa mempunyai tingkat kedisiplinan yang rendah, tetapi hasil pre test pada responden menunjukkan tingkat kedisiplinan dengan kriteria sedang. Hasil pre test yang menunjukkan kedisiplinan siswa berada pada kriteria sedang juga dapat diakibatkan dari instrumen penelitian yang digunakan yaitu skala kedisiplinan. Sedangkan kedisiplinan tidak hanya sekadar atribut psikologis saja tetapi perpaduan antara aspek psikologis dan juga perilaku yang nampak serta bisa diamati. Sehingga ketika siswa diminta untuk mengisikan instrumen skala kedisiplinan mereka cenderung memilih jawaban yang tampak ideal di masyarakat.

Analisis deskriptif pada hasil post test menunjukkan adanya peningkatan pada kondisi kedisiplinan siswa dalam menaati tata tertib. Setelah diberi layanan penguasaan konten dengan menggunakan teknik modelling simbolik dari 32 siswa kelas VII SMP Negeri 8 Tebing Tinggi terdapat 1 siswa $(3,13 \%)$ memiliki kategori sangat tinggi, 23 siswa (71,87\%) memiliki kategori tinggi dan 8 siswa $(25,00 \%)$ memiliki kategori sedang dalam hal kedisiplinan menaati tata tertib. Tidak ditemukan adanya siswa yang memiliki tingkat kedisiplinan dalam kategori rendah dan sangat rendah. Hal ini juga terlihat dari hasil pengamatan selama melakukan penelitian. Terjadi peningkatan pada ketiga indikator penelitian setelah siswa diberikan layanan penguasaan 
konten dengan menggunakan teknik modelling. Rata-rata peningkatan setiap indikator penelitian adalah $11 \%$. Indikator pemahaman tentang peraturan yang berlaku mengalami peningkatan yang palingtinggi yaitu sebesar $12 \%$. Sedangkan indikator yang persentase peningkatannya paling rendah setelah diberikan layanan penguasaan konten dengan menggunakan teknik modelling adalah kesungguhan dalam menaati tata tertib yaitu peningkatannya sebesar $10 \%$. Kondisi kedisiplinan siswa sebelum diberi perlakuan berupa layanan penguasaan konten dengan menggunakan teknik modelling berada pada kriteria sedang dengan persentase $66,6 \%$. Kemudian terjadi peningkatan menjadi $77,6 \%$ dengan kriteria tinggi, setelah diberi layanan penguasaan konten dengan teknik modelling. Dari hasil tersebut diketahui bahwa terdapat peningkatan pada kondisi kedisiplinan siswa sebesar $11 \%$. Dari hasil penelitian ini menunjukkan bahwa secara umum siswa telah memahami tentang arti dari disiplin dalam menaati tata tertib serta manfaat dari disiplin menaati tata tertib.

Selain dari perhitungan posttest, untuk dapat mengetahui bahwa kedisiplinan siswa dapat ditingkatkan melalui layanan penguasaan konten dengan teknik modelling adalah dengan melakukan analisis uji beda data penelitian pre test dan post test. Dari hasil uji beda t-test diperoleh nilai $\mathrm{t}$ hitung $=10,67$ dan nilai $\mathrm{t}$ tabel
$=2,04$ dengan taraf signifikansi 5\%. Berdasarkan hasil uji beda tersebut diketahui bahwa nilai $\mathrm{t}$ hitung $>\mathrm{t}$ tabel, maka Ho ditolak dengan kata lain Ha (hipotesis yang diajukan dalam penelitian) diterima. Apabila dikaitkan pada hipotesis yang ingin dibuktikan pada penelitian ini maka dapat dibuktikan bahwa kedisiplinan siswa dalam menaati tata tertib dapat ditingkatkan melalui layanan penguasaan konten dengan menggunakan teknik modelling pada siswa SMP Negeri 8 Tebing Tinggi. Dari hasil analisis uji beda t-test, perbandingan hasil pre-test dan posttest, dan pengamatan pada saat penelitian menunjukkan adanya perubahan positif pada kedisiplinan siswa kelas VII SMP Negeri 8 Tebing Tinggi.

\section{SIMPULAN}

Berdasarkan hasil penelitian dan pembahasan, maka dapat disimpulkan sebagai berikut:

a. Kedisiplinan siswa dalam menaati tata tertib sebelum diberi layanan penguasaan konten dengan menggunakan teknik modelling pada siswa kelas VII SMP Negeri 8 Tebing Tinggi tahun ajaran 2015/2016 berada pada kategori sedang.

b. Kedisiplinan siswa dalam menaati tata tertib setelah diberi layanan penguasaan konten dengan menggunakan teknik modelling pada siswa kelas VII SMP Negeri 8 Tebing Tinggi tahun 2015/2016 berada pada kategori tinggi. 
SEJ VOLUME 7 NO. 1 JUNI 2017

c. Terdapat perubahan yang positif yaitu berupa peningkatan yang signifikan pada kedisiplinan siswa dalam menaati tata tertib setelah diberi layanan penguasaan konten dengan menggunakan teknik modelling pada siswa kelas VII SMP Negeri 8 Tebing Tinggi tahun 2015/2016. Hasil ini didukung dengan pengamatan terhadap responden selama penelitian.

\section{DAFTAR RUJUKAN}

Arikunto, Suharsimi. 2006. Prosedur Penelitian Suatu Pendekatan Praktik. Jakarta: Rineka Cipta.

Bahri, Syamsul. 2008. Tanggung Jawab, Disiplin, Jujur itu
Keren (Pendidikan Anti Korupsi Kelas 1 SMP/MTS). Jakarta: KPK Direktorat Pendidikan dan Pelayanan Masyarakat.

Corey, Gerald. 2007. Teori dan Praktek Konseling dan Psikoterapi. Bandung: Refika Aditama.

Crain, William. 2007. Teori Perkembangan Konsep dan Aplikasi (Edisi Ketiga). Yogyakarta: Pustaka Pelajar.

Feist, Jess dan Gregory J. Feist. 2008. Theories of Personality (Edisi Keenam). Yogyakarta: Pustaka Pelajar. 